\title{
Měkkýši hradů Sion a Vízmburk - sukcese na znovuobjevených zříceninách \\ Molluscs of Sion and Vízmburk castles - succession on the reappearance ruins of castles
}

\author{
Lucie Juřičková \\ Přírodovědecká fakulta UK, Katedra zoologie, Viničná 7, CZ-12844 Praha 2, Česká republika, e-mail: \\ tomas.juricka@tiscali.cz
}

\section{Úvod}

V rámci větší studie o měkkýších našich hradů a hradních zřícenin (JUŘIČKOVÁ 2001) byla zpracována též měkkýší fauna hradů Sion a Vízmburk, které jsou jedinečné vzhledem k jejich znovuobjevení. Péčí archeologů byly totiž obě zříceniny v nedávné době doslova vykopány ze země a vznikla tak stanoviště, na nichž můžeme sledovat přesně datovaný průběh sukcese na př́kladu měkkýších společenstev jakožto modelové skupiny bezobratlých živočichů.

\section{Charakteristika zkoumaných lokalit}

Základní charakteristiky obou lokalit jsou shrnuty v níže uvedené tabulce, kde je i přehled dosud zjištěných druhů, pokud jsou z lokalit nějaké starší sběry známy.

Tabulka 1. Popis lokalit.

Table 1. The description of localities. First column $(1)=$ name of castle, $(2)=$ date and author of collecting, $(3)=$ geographical coordinates, $(4)=$ coordinates of CR zoological mapping square, $(5)=$ height above sea level, $(6)=$ geological composition of locality.

\begin{tabular}{|l|l|l|l|l|l|}
\hline Hrad (1) & $\begin{array}{l}\text { Autor a datum } \\
\text { sběru (2) }\end{array}$ & Souřadnice (3) & $\begin{array}{l}\text { Čtverec } \\
\mathbf{( 4 )}\end{array}$ & $\begin{array}{l}\text { Nadm. } \\
\text { výška } \\
\text { (5) }\end{array}$ & \begin{tabular}{l} 
Geologický podklad (6) \\
\hline Vízmburk
\end{tabular} \\
\hline $\begin{array}{l}\text { Juřičková } \\
2.8 .1998\end{array}$ & $\begin{array}{l}50^{\circ} 29^{\prime} 06.83^{\prime \prime} \\
16^{\circ} 02^{\prime} 55.67^{\prime \prime}\end{array}$ & $5562 \mathrm{a}$ & $400 \mathrm{~m}$ & $\begin{array}{l}\text { kaolinické pískovce spodní- } \\
\text { ho triasu }\end{array}$ \\
\hline
\end{tabular}

Hrad (z bílého tabulového pískovce) ze 13. století stával v ohbí řeky Úpy uprostřed lesů a zanikl někdy v 16. století. V roce 1972 začaly výkopové práce a v průběhu 70 let byly zříceniny doslova vykopány ze země. Kolem je kulturní smrkový les, u hradu kleny a buky.

Starší sběry: BRABENEC (1978): Arion fasciatus, Deroceras praecox

\begin{tabular}{|l|l|l|l|l|l|}
\hline Sion & Juřičková & $\begin{array}{l}49^{\circ} 43^{\prime} 21.29^{\prime \prime} \\
15^{\circ} 12^{\prime} 38.37^{\prime \prime}\end{array}$ & $6157 \mathrm{a}$ & $370 \mathrm{~m}$ & $\begin{array}{l}\text { orthoruly kutnohorského } \\
\text { krystalinika }\end{array}$ \\
\hline
\end{tabular}

Zbytek zrríceniny turisticky upravené leží na skalnatém ostrohu na pravém břehu říčky Vrchlice na místě bývalého hradiště. Vlastní hrad byl vybudován až v polovině 15. století a v zápětí byl dobyt, takže za sto let už z něho byly patrné jen obvodové zdi a koncem minulého století z něho zbyly už jen zbytky zdí zasypané hlínou, tyto zbytky byly vykopány a konzervovány v 60. letech 20 . století, kdy byl také v areálu hradu vykácen les. Dnes kryje stráně kolem hradu les - habr, dub, javor klen, na vlastní zřícenině rostou mladé duby, břízy, osiky a vrby a sešlapávaný trávník s krvavcem totenem.

\section{Metodika}

Při návštěvě obou lokalit byl proveden individuální sběr a byly odebrány hrabankové vzorky, které byly dále standardním způsobem popsaným např. v práci LOŽKA (1956) zpracovány.

\section{Výsledky}

Výsledky jsou shrnuty do přehledné tabulky. 
Tabulka 2. Seznam druhů (čísla udávají počet jedinců ve standardním harbankovém vzorku).

Table 2. List of species (the numbers signify number of individuals in standard soil sample).

\begin{tabular}{|l|c|c|}
\hline Druh (Species) & Sion (castle) & Vízmburk (castle) \\
\hline Cochlicopa lubrica & 10 & \\
\hline Cochlicopa lubricella & 10 & 1 \\
\hline Truncatellina cylindrica & 4 & \\
\hline Columella edentula & 5 & \\
\hline Vertigo pygmaea & 3 & \\
\hline Vertigo pusilla & 17 & \\
\hline Vallonia costata & 43 & \\
\hline Vallonia pulchella & 31 & \\
\hline Vallonia excentrica & 1 & 15 \\
\hline Acanthinula aculeata & 7 & 205 \\
\hline Punctum pygmaeum & 8 & \\
\hline Discus rotundatus & 82 & 181 \\
\hline Arion silvaticus & + & 2 \\
\hline Arion subfuscus & + & 24 \\
\hline Vitrina pellucida & 31 & 34 \\
\hline Semilimax semilimax & & \\
\hline Vitrea diaphana & & \\
\hline Aegopinella minor & 17 & 12 \\
\hline Perpolita hammonis & 27 & \\
\hline Oxychilus cellarius & 6 & \\
\hline Daudebardia rufa & 6 & \\
\hline Deroceras agreste & + & \\
\hline Deroceras reticulatum & + & \\
\hline Malacolimax tenellus & + & \\
\hline Boettgerilla pallens & + & \\
\hline Euconulus fulvus & 6 & \\
\hline Alinda biplicata & 191 & \\
\hline Succinella oblonga & 6 & \\
\hline Monachoides incarnatus & 29 & \\
\hline Trichia hispida & 21 & \\
\hline Euomphalia strigella & 7 & \\
\hline Helicigona lapicida & 8 & \\
\hline Helicodonta obvoluta & 2 & \\
\hline Causa holosericea & & \\
\hline Celkem zjištěno druhů (number of species & & \\
recorded): & & \\
\hline & & \\
\hline
\end{tabular}

\section{Diskuse}

K odkrytí hradu Sionu došlo v průběhu 60. let 20. století a sukcese tu tedy probíhá necelých 40 let. Hrad je obklopen lesem, který má směrem k potoku dosti přirozený ráz (habr, dub, klen). Je jasné, že se sem šiřily především druhy, žijící v bezprostředním okolí, jako Columella edentula, Acanthinula aculeata, Discus rotundatus, Oxychilus cellarius, Alinda biplicata, Trichia hispida, Malacolimax tenellus, Monachoides incarnatus a snad i Helicigona lapicida a Daudebardia rufa. Skupina pionýrských druhů, tedy druhů, které u nás přežily glaciál a jsou charakteristické pro počáteční stadia sukcese, je zde zastoupena $v$ plném počtu a také kvantitativně se podílí na složení společenstva výrazně více, než je na hradech obvyklé (JUŘIČKOVÁ 2001). Hradní společenstva se totiž jinak vyznačují poměrně nízkým podílem těchto druhů a to jak kvantitativně, tak kvalitativně, což můžeme obecně interpretovat jako důkaz stability hradních měkkýších společenstev. Druh sušších pláštových formací Euomphalia strigella sem patrně doputoval z nedalekých křovin na okrajích pole stejně jako nazí plži Deroceras agreste a D. reticulatum. Další skupinou jsou druhy otevřených druhotných stanovišt', které zde před vykopáním hradu nemohly žít (byl zarostlý lesem). Jedná se o druhy Cochlicopa lubricella, Truncatellina cylindrica, Vertigo pygmaea, Vallonia costata, $V$. pulchella a $V$. excentrica. Tyto druhy se sem musely dostat výsadkem za pomoci zvířat a 
to v některých př́ipadech na vzdálenost několika kilometrů, přičemž překvapuje vysoký počet druhů za relativně krátkou dobu. Největším překvapením je však výskyt dvou citlivých druhů lesních sutí Helicodonta obvoluta a Causa holosericea, jejichž společný výskyt je vzhledem k jejich nárokům dost netypický (známe jej snad jen z Křivoklátska a Hřebenů) nehledě k tomu, že se v širším okolí nevyskytují. H. obvoluta je totiž teplomilý prvek, zatímco $C$. holosericea je druh vyššího mezofytika a oreofytika. Jak se sem dostali, zůstává záhadou. Každopádně je společenstvo 32 druhů, které se zformovalo za necelé čtyři desítky let, značným překvapením.

Hrad Vízmburk byl vykopán zhruba o deset let později (v průběhu 70. let) a hlavní překážkou sukcese zdejších společenstev je jeho izolovanost uprostřed kulturních lesů, vesměs smrkových monokultur. Zde mají jistě původ dva dominantní druhy Vitrina pellucida a Discus rotundatus i další druhy ze skupiny druhů pionýrských. Opět zde nalezneme dva druhy otevřených stanovišt'Truncatellina cylindrica a Vallonia costata, které musely zříceninu osídlit dálkovým výsadkem. Největším překvapením je však výskyt tří citlivých lesních druhů Vitrea diaphana, Semilimax semilimax a Daudebardia rufa, které snad obývaly zalesněnou hradní lokalitu ještě před vykopáním zř́íceniny díky místnímu obohacení půdy vápníkem. Pozoruhodná je poznámka J. Brabence, který navštívil zříceninu bezprostředně po jejím vykopání a nalezl zde pouze dva druhy nahých plžů, kteří zde však už potvrzeni nebyli (BRABENEC 1978). I přes značnou izolaci této zř́iceniny se tedy za dvacet let zvýšil počet zde žijících druhů o 10.

\section{Závěr}

Zříceniny Vízmburk a Sion představují naprosto ojedinělé dlouhodobé ekologické pokusy, umožňující nám sledovat sukcesi na těchto unikátních stanovištích. Už nyní můžeme říci, že osidlování těchto lokalit měkkýši je nad očekávání rychlé a je nepř́mým důkazem toho, že se měkkýši běžně širíi dálkovými výsadky. Tyto pokusy $\mathrm{v}$ přírodě budou pochopitelně vyžadovat následné revize.

\section{Summary}

Castles Sion near Kutná Hora and Vízmburk near Trutnov were completely excavated 40 and 30 years ago. We can therefore monitor the succession in these localities. In the castle Sion there now live 32 species (with species isolated in this locality Helicodonta obvoluta and Causa holosericea). 12 species living in Vízmburk is also a relatively high number in view of the fact that this castle is completely isolated in spruce monoculture. These castles are indirect evidence of long-range transport of snails by birds and other animals. Both localities represent the long-term ecologic experiment.

\section{Literatura}

BRABENEC J., 1978: K poznání měkkýšů východních Čech. - Práce a studie - Př́r., Pardubice, 10: 87-108.

JUŘIČKOVÁ L., 2001: Měkkýší společenstva měst a hradů jako modelový př́klad vlivů člověka na společenstva bezobratlých živočichů. - Doktorandská disertační práce. Depon. In: Zoologická knihovna katedry zoologie UK Praha.

LOŽEK V., 1956: Klíč k určování československých měkkýšů. - SAV, Bratislava, 437 pp. 